Mutation Research, 90 (1981) 67-78

Elsevier/North-Holland Biomedical Press

\title{
BACTERIAL MUTAGENICITY AND TOXICITY OF CYCLOALIPHATIC EPOXIDES
}

\author{
S.W. FRANTZ and J.E. SINSHEIMER * \\ College of Pharmacy, The University of Michigan, Ann Arbor, MI 48109 (U.S.A.) \\ (Received 17 November 1980) \\ (Revision received 13 March 1981) \\ (Accepted 29 April 1981)
}

\section{Summary}

The mutagenicity of 12 cycloaliphatic epoxides was investigated using the Ames Salmonella assay without the addition of liver homogenate fractions. Base-pair substitution mutagenic activity was detected for 8 members of this series of compounds, confirming our laboratory's previous observations of weak mutagenic response at high dose levels for cis-1,2-disubstituted epoxides. While mutagenicity decreased with expanding ring size, inhibition of bacterial growth increased for increases in ring size. Toxicity accompanying the required high doses for the demonstration of mutagenicity for these compounds prevented the establishment of meaningful dose-response ranges for the remaining epoxides tested. The volatility observed with these oxiranes also made doseresponse establishment difficult but was countered by the use of petri dish sealing bands during incubation. Mutagenicity in this series was found to be generally more pronounced in TA1535 while toxicity was detected with greater sensitivity by TA100. The use of the less permeable strains TA92, TA1950 and TA2410, all having normal lipopolysaccharide cell wall coatings, failed to reduce this marked toxicity. The repair test compared results in TA1535 (repair-deficient strain) with TA1975 (repair-proficient strain) and demonstrated that the bacteria were not being killed by damage to DNA since toxicity was not reduced in TA1975.

References in the literature to the mutagenicity of cycloaliphatic epoxides are limited **. Thus, while it is well established that biological arene oxide transformation can lead to cyclic aliphatic epoxides such as the 7,8-diol-9,10-epoxide metabolite of benzo[ $a]$ pyrene that are highly mutagenic (Gelboin and Ts'o,

\footnotetext{
* To whom correspondence should be addressed.

** Note added in proof: See Jung et al., Mutation Res., 81 (1981) 11-19, for a report on the mutagenicity of 17 cycloaliphatic epoxides.
} 
1978; Lehr and Jerina, 1977; Newbold and Brooks, 1976; Thakker et al., 1976; Wislocki et al., 1976; Yagi et al., 1977a,b) little has been reported concerning the mutagenicity of less complex cycloaliphatic epoxides. Previous work in these laboratories on the mutagenicity of aliphatic epoxides indicated that among the limited number of 1,2-disubstituted epoxides tested only structures having a cis configuration about the oxirane ring were mutagenic (D.R. Wade et al., 1978). Cyclohexane oxide was one of the 1,2-disubstituted compounds found to be a weak mutagen in the Ames test for TA100. Watabe et al. (1980) also reported this compound to be a weak mutagen in the Ames test for TA100. In addition, the latter study found vinylcyclohexane dioxide to be weakly mutagenic in TA100. Other investigations have shown this diepoxide to be mutagenic for both TA100 and TA1535 in the plate incorporation test (ElTantawy and Hammock, 1980) and mutagenic for TA100 but not for TA98 in the spot-test version of the Ames test (M.J. Wade et al., 1979). The mutagenicity of 1,2,5,6-diepoxycyclooctane was assessed by the use of Chinese hamster lung-cell culture and found to be totally inactive (Huang et al., 1978). The carcinogenicity of vinylcyclohexane dioxide (Christensen, 1974; Van Duuren et al., 1966) and the non-carcinogenicity of 1,2,5,6-diepoxycyclooctane (Van Duuren et al., 1967; Van Duuren, 1969) in rodent systems has been firmly established.

The present investigation focuses on the expansion of Ames mutagenicity testing with Salmonella for cycloaliphatic oxiranes as examples of cis-1,2-disubstituted aliphatic epoxides. The series has been expanded to include 9 cycloalkane and 3 cycloalkene epoxides. The role of toxic interference in the establishment of mutagenic dose-response for these compounds is discussed.

\section{Materials and methods}

Cyclopentane oxide (97\% purity), cyclohexane oxide (98\% purity), cyclooctane oxide (99\% purity), cyclododecane oxide (97\% purity), exo-2,3-epoxynorbornane (98\% purity), 4-vinylcyclohexane dioxide (99\% purity) and 1,2,5,6diepoxycyclooctane (97\% purity) were obtained from Aldrich Chemical Company (Milwaukee, WI). Cycloheptane oxide and 1-oxaspiro[2.5]octane were acquired from the ABC Rare Chemical Division of Aldrich (purity unspecified).

3,4-Epoxycyclopentene, 3,4-epoxycyclohexene and 4,5-epoxycyclohexene were synthesized by the method of Crandall et al. (1968) from the respective cyclodienes. 1,3-Cyclohexadiene (96\% purity) and 1,4-cyclohexadiene (97\% purity) were purchased from Aldrich while 1,3-cyclopentadiene was freshly prepared (Moffett, 1963) from its dimer, dicyclopentadiene (Phillips Chemical, Bartlesville, OK).

All chemicals were analyzed for the absence of trace alkylating impurities using 4-( $p$-nitrobenzyl)-pyridine (Aldrich) by the method of Hammock, et al. (1974) in 2 TLC systems: normal phase using dichloromethane on 250-micron Silicar 7GF plates (Analtech, Newark, DA) and reverse phase with methanol on 250-micron C18 RPS fluorescent plates (Analtech). The structures for the commercially available and synthesized epoxides were confirmed by NMR and IR spectrometry.

Bacteria used for this testing were the specially constructed histidine-dependent mutants of Salmonella typhimurium. The mutagenesis assays were accom- 
plished by a modified version of the Ames method (Ames et al., 1975). The cultures were grown up overnight $(20-\mathrm{ml}$ inoculum volumes of nutrient broth, Difco, Detroit, MI) in Nephalo culture flasks containing spectrophotometric sidearms (Bellco Biological Glassware, Vineland, NJ). The cultures were grown to the absorbance range of $0.78-0.83$ at $560 \mathrm{~nm}$ (Spectronic 20, Bausch and Lomb, Rochester, NY) which produced spontaneous reversion counts of 1525 for TA1535 and 70-120 for TA100. Compounds were dissolved in dimethylsulfoxide on the day of the test and $0.1-\mathrm{ml}$ portions were added to $2 \mathrm{ml}$ of molten $\left(45^{\circ} \mathrm{C}\right.$ ) top agar (Ames et al., 1973) together with $0.1 \mathrm{ml}$ of bacterial suspension (which under our conditions resulted in $3-6 \times 10^{8}$ cells for TA100 and $8-11 \times 10^{8}$ cells for TA1535) and plated onto minimal-glucose (1.5\% BBL agar [Becton, Dickenson and Co., Cockeysville, MD] in Vogel-Bonner Medium $\mathrm{E}$ with $2 \%$ glucose) as described (Ames et al., 1975). The test-dose levels were done in triplicate (Falcon "Muta-Assay" plates, Oxnard, CA) and control plates were treated in the same manner but without test compound.

In addition, strains were also used for this study which contained a normal lipopolysaccharide cell-wall coating [TA92 (hisG46/pKM101), TA1950 (hisG46/ $\Delta u v r B$ ) and TA2410 (TA1950/pKM101) as well as a strain which contained the normal complement of enzyme-repair systems [TA1975 (hisG46/ rfa)]. Test cultures for these strains were prepared as described by Ames et al. (1975) using overnight ( $15 \mathrm{~h}$ ) cultures.

Positive mutagen controls were routinely included in test protocols. Sodium azide (Pfaltz and Bauer, Stamford, CN) was used for both TA100 and TA1535. Bacterial survival was determined by combining mutagenicity test doses of the compounds with $10^{-5}$ dilutions of the bacterial cultures (300-600 cells/plate for TA100 and 800-1100 cells/plate for TA1535) on nutrient agar (BBL, Becton, Dickenson and Co., Cockeysville, MD) plates. The use of petri dish sealing bands (Fisher Scientific, Pittsburgh, PA) was routinely employed to prevent the loss of volatile compounds during the $48 \mathrm{~h}$ incubation period.

\section{Results and discussion}

The cycloaliphatic epoxides tested in this investigation are listed in Table 1. In general, these alicyclic oxiranes possess a cis-1,2-disubstituted stereochemistry about the epoxide ring. One exception is compound 9, oxaspirooctane, a 1,1-disubstituted oxirane which was of interest because the hydrocarbon ring moiety represents restricted rotation for the cyclohexane ring carbons analogous to that for the 1,2-disubstituted cycloaliphatic epoxides.

Preliminary screening tests with the 5 conventional tester strains, TA98, TA100, TA1535, TA1537 and TA1538, demonstrated mutagenic activity only in the base-pair indicator strains, TA100 and TA1535. The results of nonactivated mutagenicity assays in these 2 strains for the cycloalkane epoxides (1-2, $6-9)$ and the cycloalkene oxiranes $(11,12)$ which are not complicated by toxic inhibition are shown in Table 2. Duplicate runs of these tests, to confirm the reproducibility of the data, are presented in Table 2 as the second result under each dose level and are consistent with day-to-day variation under standardized experimental conditions observed for the Ames technique (Cheli et al., 1980; Peak et al., 1980). Compounds 1, 2, 6, 8, 11 and 12 were found to be muta- 
TABLE 1

COMPOUNDS TESTED

\begin{tabular}{|c|c|c|c|}
\hline No. & Name & $\begin{array}{l}\text { Molecular } \\
\text { weight }\end{array}$ & Structure \\
\hline 1 & $\begin{array}{l}\text { Cyclopentane oxide } \\
\text { (6-oxabicyclo }[3.1 .0] \text { hexane) }\end{array}$ & 84.12 & \\
\hline 2 & $\begin{array}{l}\text { Cyclohexane oxide } \\
\text { (7-oxabicyclo[ } 4.1 .0] \text { heptane) }\end{array}$ & 98.15 & \\
\hline $\mathbf{3}$ & $\begin{array}{l}\text { Cycloheptane oxide } \\
\text { (8-oxabicyclo[5.1.0] octane) }\end{array}$ & 112.17 & \\
\hline 4 & $\begin{array}{l}\text { Cyclooctane oxide } \\
\text { (9-oxabicy clo }[6.1 .0] \text { nonane) }\end{array}$ & 126.20 & \\
\hline 5 & $\begin{array}{l}\text { Cyclododecane oxide } \\
\text { (13-oxabicyclo[10.1.0] tridecane) }\end{array}$ & 182.31 & \\
\hline 6 & $\begin{array}{l}\text { Norboxnane oxide, exo-2,3- } \\
\text { (3-oxatricy clo }\left[3.2 .1 .0^{2}, 4\right] \text { octane) }\end{array}$ & 110.16 & \\
\hline 7 & $\begin{array}{l}\text { Diepoxycyclooctane, } 1,2,5,6- \\
\left.\text { (5,10-dioxatricyclo }\left[7,1.0 .0^{4}, 6\right] \text { decane }\right)\end{array}$ & 140.18 & \\
\hline 8 & $\begin{array}{l}\text { Vinylcy clohexane dioxide } \\
\text { (3-oxiranyl-7-oxabicyclo[ } 4.1 .0] \text { heptane) }\end{array}$ & 140.18 & \\
\hline 9 & $\begin{array}{l}\text { Oxaspirooctane } \\
\text { (1-oxaspiro[2.5]octane) }\end{array}$ & 112.17 & \\
\hline 10 & $\begin{array}{l}\text { Cyclopentene-3,4,epoxide } \\
\text { (6-oxabicyclo[3.1.0]hex-2-ene) }\end{array}$ & 82.12 & \\
\hline 11 & $\begin{array}{l}\text { Cyclohexene-3,4-epoxide } \\
\text { (7-oxabicy clo[4.1.0] hept-2-ene) }\end{array}$ & 96.15 & \\
\hline 12 & $\begin{array}{l}\text { Cyclohexene-4,5-epoxide } \\
\text { (7-oxabicyclo[4.1.0]hept-3-ene) }\end{array}$ & 96.15 & \\
\hline
\end{tabular}

genic for both strains. Oxaspirooctane (9) was weakly mutagenic only for TA100 and diepoxycyclooctane (7) was inactive in both strains. The order of positive mutagenic response in TA100 is: vinylcyclohexane dioxide (8) $\gg$ cyclopentane oxide $(1)>4,5$ epoxycyclohexene $(12) \approx$ cyclohexane oxide (2) > norbornane oxide (6) > 3,4-epoxycyclohexene (11) $>$ oxaspirooctane (9). However, for TA1535 the order is: 4,5-epoxycyclohexene (12) $>$ cyclopentane oxide $(1)>$ cyclohexane oxide $(2) \approx$ norbornane oxide $(6)>$ vinylcyclohexane oxide $(8)>3,4$ epoxycyclohexene (11). In both strains, mutagen- 


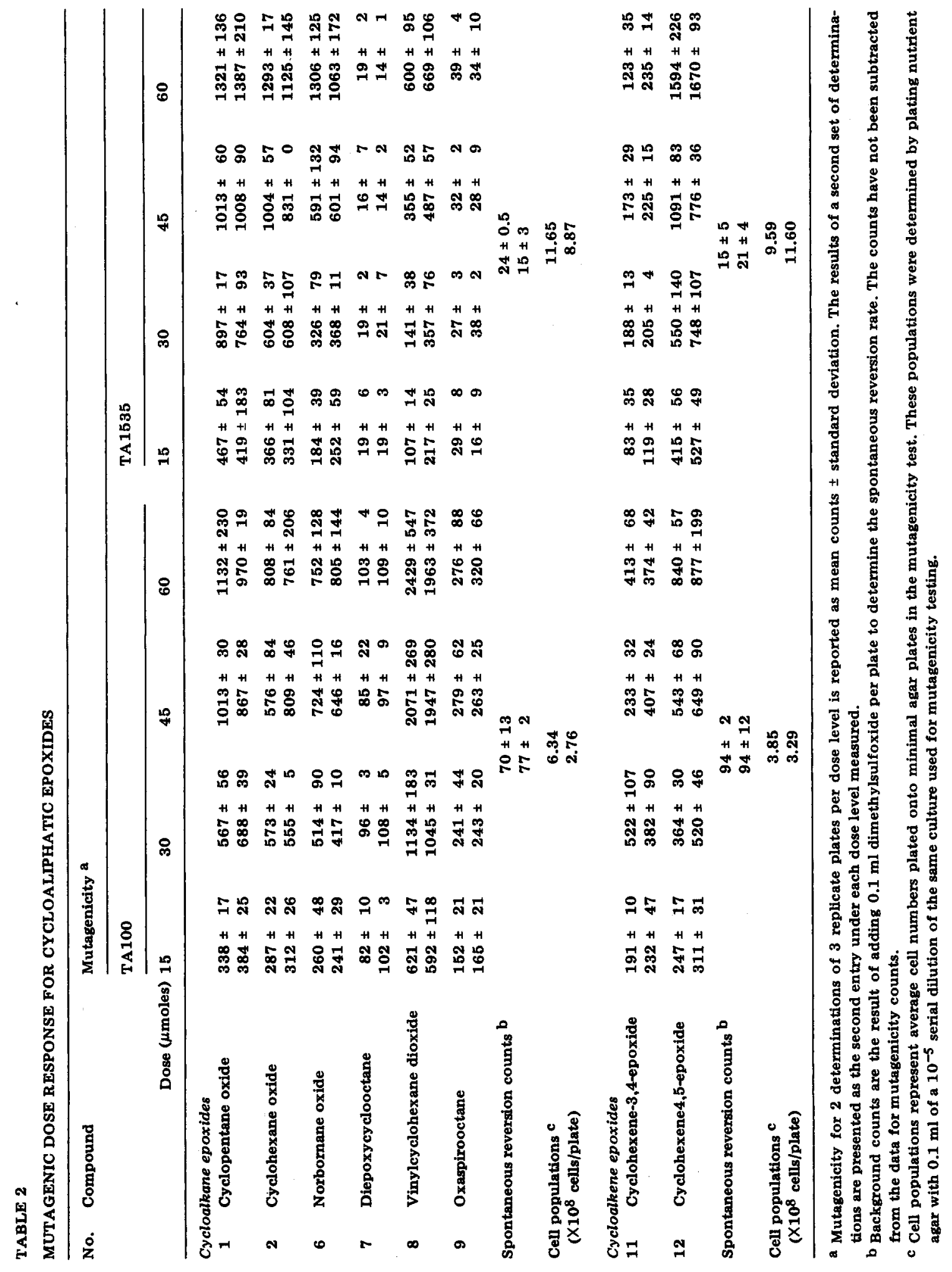


icity could only be demonstrated for the compounds with 5- or 6-membered rings.

Under the conditions of this test, mutagenicity for these compounds was generally found to be more pronounced in TA1535 than in TA100, with the exceptions of vinylcyclohexane dioxide (8) and oxaspirooctane (9). The influence of toxic inhibition varied with compounds and strains, complicating a comparison of mutagenicity between the 2 strains. The findings of this study are in agreement with previous investigations (El-Tantaway and Hammock, 1980; M.J. Wade et al., 1979; Watabe et al., 1980) of mutagenicity in the Ames test for vinylcyclohexane dioxide (8). The higher dose levels used for cyclohexane oxide (2) in the present study extended the literature reports (D.R. Wade et al., 1978; M.J. Wade et al., 1979) of mutagenicity in TA100 only by demonstrating greater mutagenicity for TA1535 than for TA100. The weak mutagenic dose-response found in TA100 for oxaspirooctane (9) with its

TABLE 3

COMPARATIVE TOXICITY FOR CYCLOALIPHATIC EPOXIDES

\begin{tabular}{|c|c|c|c|c|}
\hline \multirow[t]{2}{*}{ No. } & \multirow[t]{2}{*}{ Compounds } & \multirow{2}{*}{$\begin{array}{l}\text { Dose } \\
\text { ( } \mu \text { moles/plate) }\end{array}$} & \multicolumn{2}{|c|}{ Relative toxicity (\% inhibition) ${ }^{a}$} \\
\hline & & & TA100 & TA1535 \\
\hline 1 & Cyclopentane oxide & $\begin{array}{l}48 \\
60\end{array}$ & $\begin{array}{r}0 \\
10\end{array}$ & $\begin{array}{l}2 \\
7\end{array}$ \\
\hline 2 & Cyclohexane oxide & $\begin{array}{l}48 \\
60\end{array}$ & $\begin{array}{l}40 \\
44\end{array}$ & $\begin{array}{l}50 \\
58\end{array}$ \\
\hline 3 & Cycloheptane oxide & $\begin{array}{l}48 \\
60\end{array}$ & $\begin{array}{l}88 \\
90\end{array}$ & $\begin{array}{l}73 \\
85\end{array}$ \\
\hline 4 & Cyclooctane oxide & $\begin{array}{l}48 \\
60\end{array}$ & $\begin{array}{l}96 \\
99\end{array}$ & $\begin{array}{l}89 \\
97\end{array}$ \\
\hline $\mathbf{5}$ & Cyclododecane oxide & $\begin{array}{l}48 \\
60\end{array}$ & $\begin{array}{l}100 \\
100\end{array}$ & $\begin{array}{l}100 \\
100\end{array}$ \\
\hline 6 & Norbornane oxide & $\begin{array}{l}48 \\
60\end{array}$ & $\begin{array}{l}49 \\
64\end{array}$ & $\begin{array}{l}17 \\
\mathbf{3 0}\end{array}$ \\
\hline 7 & Diepoxycyclooctane & $\begin{array}{l}48 \\
60\end{array}$ & $\begin{array}{r}9 \\
10\end{array}$ & $\begin{array}{l}\mathbf{0} \\
\mathbf{0}\end{array}$ \\
\hline 8 & Vinylcy clohexane dioxide & $\begin{array}{l}48 \\
60\end{array}$ & $\begin{array}{r}6 \\
12\end{array}$ & $\begin{array}{r}8 \\
15\end{array}$ \\
\hline $\mathbf{9}$ & Oxaspriooctane & $\begin{array}{l}48 \\
60\end{array}$ & $\begin{array}{l}46 \\
60\end{array}$ & $\begin{array}{l}57 \\
76\end{array}$ \\
\hline $\begin{array}{l}\text { Cycl } \\
10\end{array}$ & $\begin{array}{l}\text { alkene epoxides } \\
\text { Cyclopentene-3,4-epoxide }\end{array}$ & $\begin{array}{l}45 \\
60\end{array}$ & $\begin{array}{l}100 \\
100\end{array}$ & $\begin{array}{l}100 \\
100\end{array}$ \\
\hline 11 & Cyclohexene-3,4-epoxide & $\begin{array}{l}45 \\
60\end{array}$ & $\begin{array}{r}2 \\
17\end{array}$ & $\begin{array}{l}12 \\
23\end{array}$ \\
\hline 12 & Cyclohexene-4,5-poxide & $\begin{array}{l}45 \\
60\end{array}$ & $\begin{array}{l}4 \\
0\end{array}$ & $\begin{array}{r}5 \\
10\end{array}$ \\
\hline
\end{tabular}

a Toxic inhibition of bacterial growth is reported as the average $\%$ growth inhibition for at least 2 determinations of 3 replicate plates per dose level tested as compared to a positive growth control group in which only $0.1 \mathrm{ml}$ dimethylsulfoxide per plate is added. Test compound doses in $0.1 \mathrm{ml}$ dimethylsulfoxide were plated onto nutrient agar plates with $0.1 \mathrm{ml}$ of a $10^{-5}$ serial dilution of the culture used for mutagenesis testing. Only the high dose levels were tested. 
TABLE 4

COMPARATIVE MUTAGENICITY FOR THE EXPANDING RING CYCLOALKANE EPOXIDES

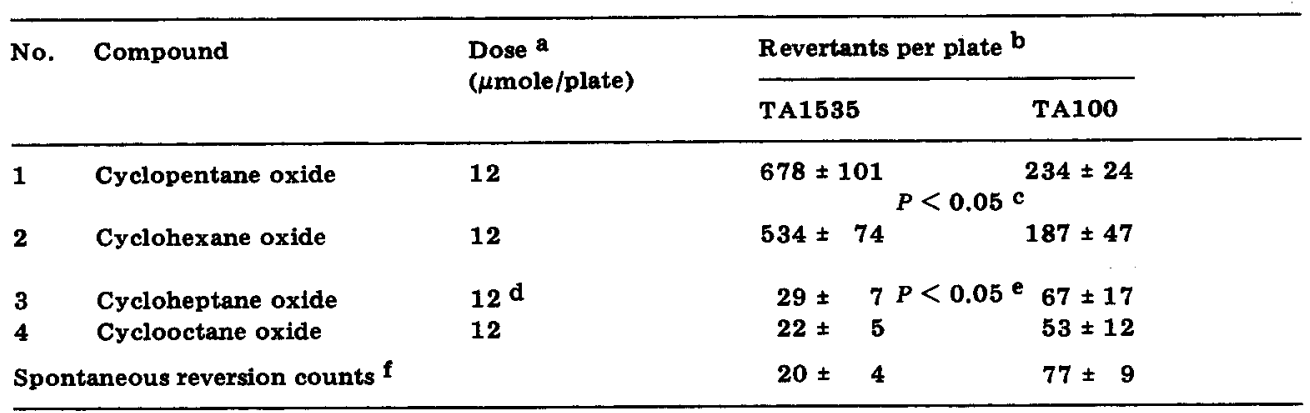

Test compound is dissolved in $0.1 \mathrm{ml}$ dimethylsulfoxide per plate.

b Mutagenicity for 6 replicates per compound is reported as mean counts \pm standard deviation. Background counts are not subtracted.

c Statistical comparison of results for compounds 1 and 2 in TA1535 using a one-sided Student's $t$-test.

d This compound was only partially soluble in dimethylsulfoxide and was delivered to the plates as a suspension rather than a solution.

e Statistical comparison of results for compound 3 with spontaneous reversion counts in TA1535 using a one-sided Student's $t$-test.

f See note b, Table 2 .

restricted rotation at the oxirane ring is another exception to the general rule that 1,1-disubstituted epoxides are inactive as mutagens (D.R. Wade et al., 1978). The atypical lack of mutagenicity for diepoxycyclooctane (7) observed in this investigation was also found by Huang and coworkers (1978) in a mammalian cell culture. The view that diepoxides of this type are frequently more carcinogenic than monoepoxide compounds (Van Duuren, 1969; Weil, 1963) cannot be extended for mutagenicity with diepoxycyclooctane in the Ames system.

The toxicity observed for cycloaliphatic epoxides made the establishment of meaningful dose-response relationships difficult. The assessment of toxicity at high dose levels for all compounds tested is summarized in Table 3. Toxic inhibition is very pronounced for cycloheptane oxide (3), cyclooctane oxide (4), cyclododecane oxide (5), as well as 3,4-epoxycyclopentane (10) and none of these compounds demonstrated a mutagenic dose-response. This was evidenced by a reduction in the number of revertant colonies observed to be well below background and a disappearance of the background lawn normally present. In addition, compounds 5 and 10 were lethal to the bacteria at concentrations larger than 12 and $15 \mu$ moles respectively in both strains. Toxic inhibition of bacterial growth made it impossible to correlate the mutagenic activity of cycloaliphatic epoxides to structural features such as ring size, degree of ring strain and degree of planar conformation.

A structure-toxicity relationship, however, did emerge from this work in that toxicity increased with expanding ring size for the homologous epoxide series composed of compounds 1-5 (Table 3). Conversely, a decrease in mutagenicity with expanding ring size is observed for these same compounds as expressed in Table 4 with multiple tests at the same dose. Cyclododecane oxide (5) was tested in the same manner but demonstrated no viable colonies even at the $12-\mu$ mole dose level selected to minimize toxic inhibition of growth. The 
TABLE 5

MUTAGENICITY OF CYCLOALKENE EPOXIDES IN THE SPOT TEST

\begin{tabular}{|c|c|c|c|c|c|c|}
\hline \multirow[t]{2}{*}{ No. } & \multirow[t]{2}{*}{ Compound } & \multirow{2}{*}{$\begin{array}{l}\text { Dose a } \\
(\mu \text { moles })\end{array}$} & \multicolumn{2}{|l|}{ TA100 } & \multicolumn{2}{|l|}{ TA1535 } \\
\hline & & & $\begin{array}{l}\text { Revertants } \\
\text { per plate }\end{array}$ & $\begin{array}{l}\text { Toxic } \\
\text { zone } \\
(\mathrm{mm})\end{array}$ & $\begin{array}{l}\text { Revertants } \\
\text { per plate }\end{array}$ & $\begin{array}{l}\text { Toxic } \\
\text { zone } \\
\text { (mm) b }\end{array}$ \\
\hline \multicolumn{7}{|c|}{ Expanding ring series } \\
\hline 1 & Cyclopentane oxide & $\begin{array}{l}30 \\
50\end{array}$ & $\begin{array}{l}352 \\
679\end{array}$ & $\begin{array}{l}0.5 \\
0.5\end{array}$ & $\begin{array}{l}1000 \\
1246\end{array}$ & $\begin{array}{l}0.5 \\
0.5\end{array}$ \\
\hline 2 & Cyclohexane oxide & $\begin{array}{l}30 \\
\mathbf{5 0}\end{array}$ & $\begin{array}{l}338 \\
552\end{array}$ & $\begin{array}{l}0 \\
0\end{array}$ & $\begin{array}{r}646 \\
1006\end{array}$ & $\begin{array}{l}0.5 \\
0.5\end{array}$ \\
\hline 3 & Cycloheptane oxide & $\begin{array}{l}30 \\
50\end{array}$ & $\begin{array}{l}73 \\
65\end{array}$ & $\begin{array}{l}2.0 \\
3.5\end{array}$ & $\begin{array}{l}20 \\
36\end{array}$ & $\begin{array}{l}2.0 \\
3.0\end{array}$ \\
\hline 4 & Cyclooctane oxide & $\begin{array}{l}30 \mathrm{c} \\
50^{\mathrm{c}}\end{array}$ & $\begin{array}{l}39 \\
32\end{array}$ & $\begin{array}{l}2.5 \\
4.0\end{array}$ & $\begin{array}{l}10 \\
16\end{array}$ & $\begin{array}{l}1.5 \\
1.5\end{array}$ \\
\hline 5 & Cyclododecane oxide & $\begin{array}{l}30 \\
50\end{array}$ & $\begin{array}{l}0 d \\
0\end{array}$ & $\begin{array}{l}\mathbf{Z}^{\mathbf{e}} \\
\mathbf{Z}\end{array}$ & $\begin{array}{l}0 \mathrm{~d} \\
0\end{array}$ & $\begin{array}{l}z^{e} \\
z\end{array}$ \\
\hline \multicolumn{2}{|c|}{ Background $\mathbf{f}$} & 0 & 71 & 0 & 18 & 0 \\
\hline \multicolumn{2}{|c|}{ Control $\mathrm{g}$} & $\begin{array}{l}30 \\
50\end{array}$ & $\begin{array}{l}52 \\
40\end{array}$ & $\begin{array}{l}1.5 \\
1.5\end{array}$ & $\begin{array}{l}19 \\
13\end{array}$ & $\begin{array}{l}0 \\
0.5\end{array}$ \\
\hline
\end{tabular}

a Dose levels reported were spotted directly as liquid samples based on volume equivalents to $\mu \mathrm{mole}$ amounts using density values at $25^{\circ} \mathrm{C}$.

b Toxicity is expressed as the width $(\mathrm{mm})$ of the zone of inhibition of the background lawn of bactexial growth around the spot.

c This compound is the only solid in the group and $\mu$ mole amounts reported were spotted per $10 \mu \mathrm{l}$ dimethylsulfoxide.

d Indicates killing of bacterial lawn by the test compound.

e The zone of toxicity extends to the edge of the plate.

f Dimethylsulfoxide $(10 \mu \mathrm{l})$ was added per plate to determine spontaneous reversion rate.

G Cyclohexanol was used as a nonepoxide control compound of similar structure to the alicyclic epoxides and was spotted directly as a liquid sample.

result for compound 3 in TA1535 shows a statistically significant difference $(P<0.05)$ from background. The observed toxic interference makes it difficult to assess mutagenicity of these examples by this testing method.

The spot test version of the Ames assay (Ames et al., 1975) was run for compounds $1-5$ in an attempt to gain a better balance between doses that produced toxicity and those required for mutagenicity so that clearly identifiable rings of mutagenic growth might be demonstrated. However, this did not occur as the distribution of compounds was not controlled by diffusion alone but was also influenced by the volatility of the compounds. Nevertheless, the data presented in Table 5 further demonstrates the same trend for decreased mutagenicity with expanding ring size as determined by total plate counts. There is also the previously demonstrated increase in toxicity with increasing ring size indicated by the radius of the toxic zone around the initial spot.

The use of very high dose levels is required for cycloaliphatic epoxides to demonstrate only weak mutagenic dose-response and it is, therefore, not surprising that toxic inhibition is observed. These toxic effects have also reduced the reproducibility of measurements for mutagenic activity for the cycloaliphatic epoxides. There is an additional problem observed for the volatile toxic 


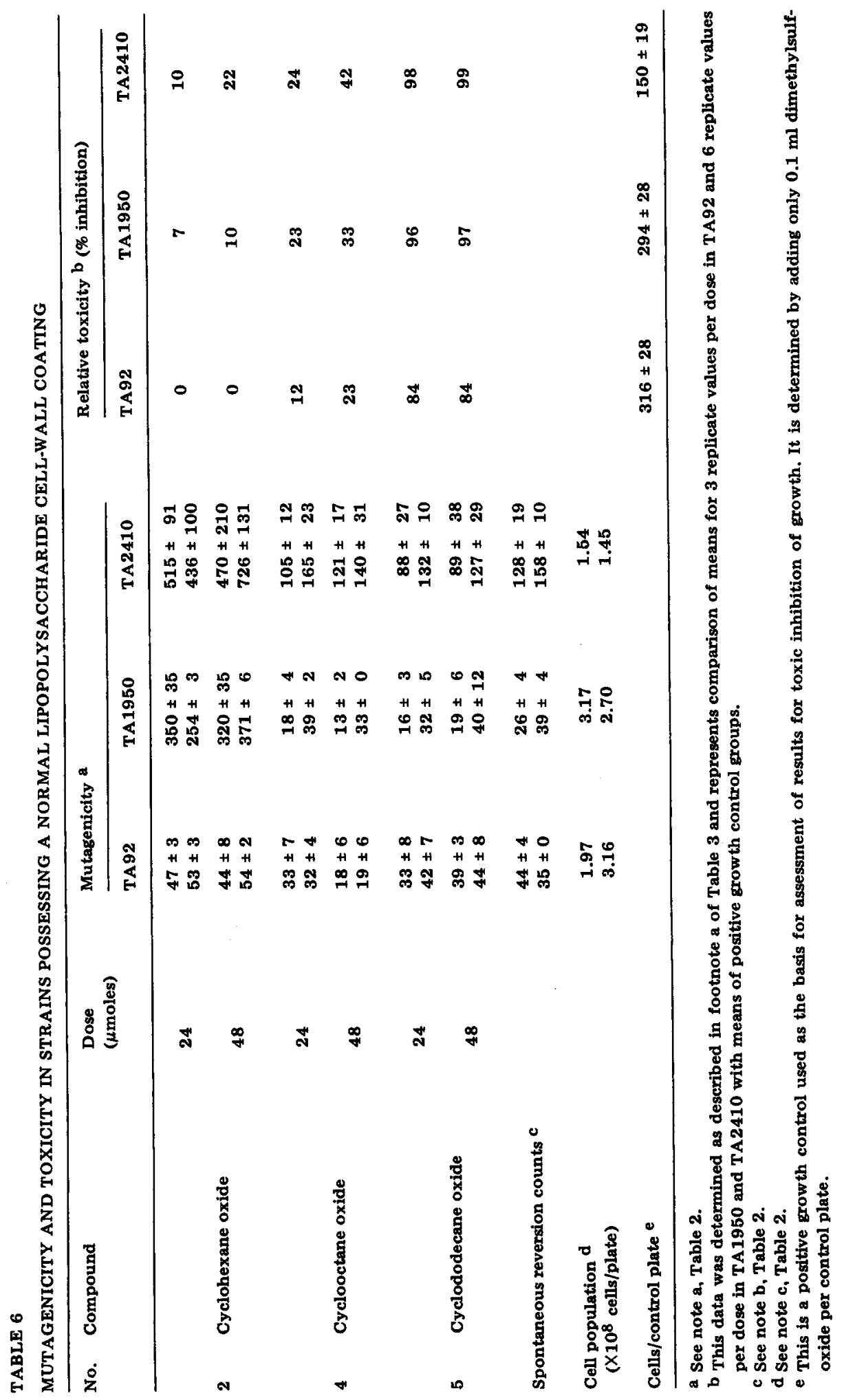


members of this epoxide group (compounds $1-5,9-12$ ) in that reproducibility is further complicated by uneven distribution and uneven loss of the compounds from replicate plates at a given dose level. Use of rubber-band petri-dish sealers prevented loss of the test compound and decreased replicate plate variation for the less toxic alicyclic epoxides tested (compounds 1-2, 11-12) but were found to increase toxicity of the more toxic compounds $(3-5,10)$.

The possibility of failing to detect a given mutagen in the Ames test because the compound is toxic to bacteria for reasons unrelated to its mutagenic potential has been raised by McCann and Ames (1977). The repair test as described by Ames et al. (1975) was employed to determine if the mechanism of toxicity was related to that of mutagenicity for the compounds under study. Although this test will not detect mutagenicity, it can indicate whether a compound is killing bacteria through damage to DNA. DNA damage can be repaired by the $u v r B$ excision-repair enzyme system which is present in these strains but has been deleted from conventional strains. Cyclooctane oxide (4) was tested with TA1975 (a repair-proficient strain) in comparison with TA1535 (a repair-deficient strain) and showed that toxicity for this epoxide was not reduced, indicating that the 2 effects do not have DNA damage as a common mechanism.

Table 6 summarizes the results of one approach to separate toxicity from mutagenicity through the use of specially constructed, base-pair mutagen detector strains, TA92, TA1950 and TA2410. Since these strains possess the normal lipopolysaccharide cell-wall coating which has been altered in TA100 and TA1535 to make the cells more permeable, such a test might reduce toxicity by diminishing entry of the epoxides into the bacterial cell while still allowing mutagenic activity to occur. The results indicate, however, that this approach has failed for compounds 2,4 and 5 to reduce the ratio of mutagenicity to toxicity in comparison to that of the conventional strains (Table 6 compared to Tables 2 and 3).

Another approach to test the presence of dose-response mutagenicity for this cycloalkane epoxide series was made based on the observation that some colonies of both TA100 and TA1535 survived the toxicity observed previously for compound 3 (Table 3). This suggested the possibility of resistance by these colonies to toxic effects of compound 3 and if so, a chance to subculture the colonies for use in a test for a dose-response demonstration. However, a check for the genotypes of these suspected colonies in histidine-depleted media revealed that the colonies were in fact histidine-independent bacteria unsuitable for further testing and is in agreement with a toxic effect described by de Serres and Shelby (1979) in which surviving bacteria give rise to small colonies which appear to be revertants.

The mutagenic response at high dose levels for compounds $1,2,6-9,11$ and 12 establishes the mutagenicity for cycloaliphatic epoxides and confirms the hypothesis that cis-1,2-disubstituted oxiranes are mutagenic. More cyclic epoxide compounds containing substituent groups should be tested to determine how such groups on reactive ring structures can alter the mutagenic potential of the oxirane ring. Such information is needed to expand our knowledge of the toxicity of cycloaliphatic epoxides per se and as metabolites in biological systems. 


\section{Acknowledgements}

The authors wish to express their appreciation to Dr. Bruce Ames, University of California at Berkeley, for supplying the Salmonella strains. This research was supported by Grant Number 1 RO1 CA 25770, awarded by the National Cancer Institute, DHHS.

\section{References}

Ames, B.N., F.D. Lee and W.E. Durston (1973) An improved bacterial test system for the detection and classification of mutagens and carcinogens, Proc. Natl. Acad. Sci. (U.S.A.), 70, $782-786$.

Ames, B.N., J. McCann and E. Yamasaki (1975) Methods for detecting carcinogens and mutagens with the Salmonella/mammalian-microsome mutagenicty test, Mutation Res., 31, 347-364.

Cheli, C., D. Francesco, L.A. Petrullo, E.C. McCoy and H.S, Rosenkranz (1980) The Salmonella mutagenicity assay: reproducibility, Mutation Res., 74, 145-150.

Christensen, H.E. (Ed.) (1974) The Toxic Substances List, U.S. Dept. of Health, Education and Welfare, Rockville, MD.

Crandall, J.K., D.B. Banks, R.A. Colyer, R.J. Watkins and J.P. Arrington (1968) A synthesis of homoallylic alcohols, J. Org. Chem., 33, 423-425.

de Serres, F J., and M.D. Shelby (1979) Recommendations on data production and analysis using the Salmonella/microsome mutagenicity assay, Mutation Res., 64, 159-165.

El-Tantawy, M.A., and B.D. Hammock (1980) The effect of hepatic microsomal and cytosolic subcellular fractions on the mutagenic activity of epoxide-containing compounds in the Salmonella assay, Mutation Res., 79, 59-71.

Gelboin, H.V., and P.O.P. Ts'o (Eds.) (1978) in: Polycyclic Hydrocarbons and Cancer; Environment, Chemistry and Metabolism, Vol. 1, Academic Press, New York, pp. 205-231.

Hammock, L.G., B.D. Hammock and J.E. Casida (1974) Detection and analysis of epoxides with 4-(pnitrobenzyl)-pyridine, Bull. Environ. Contam. Toxicol., 12, 759-763.

Huang, S.L., D.N. Rader and C.-Y. Lee (1978) The association between mutagenicity and adduct formation of 1,2,7,8-diepoxyoctane and 1,2,5,6-diepoxycy clooctane, Chem.-Biol. Interact., 20, 333-340.

Lehr, R.E., and D.M. Jerina (1977) Metabolic activations of polycy clic hydrocarbons, Structure-activity relationships, Arch. Toxicol., 39, 1-6.

McCann, J., and B.N. Ames (1977) The Salmonella/microsome mutagenicity test: predictive value for animal carcinogenicity, in: H.H. Hiatt, J.D. Watson and J.A. Winsten (Eds.), Origins of Human Cancer, Cold Spring Harbor Laboratory, New York, pp. 1431-1450.

Moffett, R.B. (1963) Cyclopentadiene and 3-chlorocyclopentene, Org. Synth., Coll. Vol. 4, $238-241$.

Newbold, R.F. and P. Brooks (1976) Exceptional mutagenicity of a benzo[a]pyrene diol epoxide in cultured mammalian cells, Nature (London), 261, 52-54.

Peak, M.J., B.S. Hass and S.S. Dornfeld (1980) Letter to the Editor, The Salmonella mutagenicity assay: reproducibility, Mutation Res., 74, 399-400.

Thakker, D.R., H. Yagi, A.Y.H. Lu, W. Levin, A.H. Conney and D.M. Jerina (1976) Metabolism of benzo[a]pyrene: Conversion of $( \pm)$-trans-7,8-dihydroxy-7,8-dihydrobenzo[a]pyrene to highiy mutagenic 7,8-diol-9,10-epoxides, Proc. Natl. Acad. Sci. (U.S.A.), 73, 3381-3385.

Van Duuren, B.C. (1969) Carcinogenic epoxides, lactones and haloethers and their mode of action, Ann. N.Y. Acad. Sci., 163, 633-651.

Van Duuren, B.C., L. Langseth, L. Orris, G. Teebor and M. Kuschner (1966) Carcinogenicity 'of epoxides, lactones and peroxy compounds, IV, J. Natl. Cancer Inst., 37, 825-838.

Van Duuren, B.C., L. Langseth, B.M. Goldschmidt and L.Orris (1967) Carcinogenicity of epoxides, lactones and peroxy compounds, VI. Structural and carcinogenic activity, J. Natl. Cancer Inst., 39 , $1217-1228$.

Wade, D.R., S.C. Airy and J.E. Sinsheimer (1978) Mutagenicity of aliphatic epoxides, Mutation Res., 58, 217-223.

Wade, M.J., J.W. Moyer and C.H. Hine (1979) Mutagenic action of a series of epoxides, Mutation Res., 66, $367-371$.

Watabe, T., A Hiratsuka, M. Isobe and N. Ozawa (1980) Metabolism of $d$-limonene by hepatic microsomes to non-mutagenic epoxides toward Salmonella typhimurium, Biochem. Pharmacol., 29, 1068-1071.

Weil, C.S., N. Condra, C. Haun and J.A. Striegel (1963) Experimental carcinogenicity and acute toxicity of representative epoxides, Am. Ind. Hyg. Assoc. J., 305-325.

Wislocki, P.G., A.W. Wood, R.L. Chang, W. Levin, H. Yagi, O. Hernandez, D.M. Jerina and A.H. Conney (1976) High mutagenicity and toxicity of a diol epoxide derived from benzo[a]pyrene, Biochem. Biophys. Res. Commun., 68, 1006-1012. 
Yagi, H., H. Akagi, D.R. Thakker, H.D. Mah, M. Koreeda and D.M. Jerina (1977a) Absolute stereochemistry of highly mutagenic 7,8-diol-9,10-epoxides derived from the potent carcinogen trans-7,8-dihydrox y-7,8-dihydrobenzo[a] pyrene, J. Am. Chem. Soc., 99, 2358-2359.

Yagi, H., D.R. Thakker, O. Hernandez, M. Koreeda and D.M. Jerina (1977b) Synthesis and reactions of the highly mutagenic 7,8-diol-9,10-epoxides of the carcinogen benzo[a]pyrene, J. Am. Chem. Soc., 99, 1604-1611. 